Conference paper (Original scientific paper)

UDC: 711.42:006.35

https://doi.org/10.18045/zbefri.2019.2.629

\title{
Do international standards influence the development of smart regions and cities?*
}

\author{
Jelena Ruso ${ }^{1}$, Ana Horvat ${ }^{2}$, Milica Maričić ${ }^{3}$
}

\begin{abstract}
The growth of city population has consequences on the sustainability and development of smart regions. International standards can provide good practices in wide areas related to environmental, security and social aspects that contribute to the achievement of economic and sustainable growth, well-being, and safe environment. The aim of this study is to explore if there is an association between the level of smart cities in different regions and the number of certificates that could initiate further development of smart and sustainable cities. We analysed standards that support the development of sustainable and smart cities from different countries and explored their influence on the level of smart and sustainable cities. To measure the performance of cities we used the UN-habitat City Prosperity Initiative (CPI) and its six dimensions: Productivity, Infrastructure Development, Quality of Life, Equity and Social Inclusion, Environmental Sustainability, and Urban Governance and Legislation. To analyse the influence of international standards on smart regions and cities initiative we conducted SEM analysis. The results of the research have proved that there is a significant difference between the level of smart cities in different regions and the number of certificates that could initiate further development of smart and sustainable cities. Additionally, a positive impact of international standards on the development of smart regions and cities is confirmed. We believe that the presented approach might provide additional insights into the factors which impact the development of smart regions and cities and initiate further studies on the topic.
\end{abstract}

Key words: international standards, smart cities, City Prosperity Initiative (CPI), SEM analysis

JEL classification: $R 11$, O44, L15, C30

* Received: 01-06-2019; accepted: 02-12-2019

1 Teaching assistant, University of Belgrade, Faculty of Organizational Sciences, Jove Ilica 154, 11000 Belgrade, Serbia. Scientific affiliation: quality management, standardization, public administration.Phone: +3813950936.E-mail:jelena.ruso@fon.bg.ac.rs (corresponding author).

2 Assistant Professor, University of Belgrade, Faculty of Organizational Sciences, Jove Ilica 154, 11000 Belgrade, Serbia. Scientific affiliation: standardization, quality management, leadership. Phone: +381113950936. E-mail: horvat.ana@fon.bg.ac.rs.

3 Teaching assistant, University of Belgrade, Faculty of Organizational Sciences, Jove Ilica 154, 11000 Belgrade, Serbia. Scientific affiliation: computational statistics, multivariate analysis, data science.Phone: +381113950822.E-mail:milica.maricic@fon.bg.ac.rs. 


\section{Introduction}

As a result of growing city population, smart regions and cities are attracting more attention from government representatives over the world. In recent years, the concept of a smart city has been overly discussed as well as initiatives to establish cities as centres for economic growth with smart and sustainable usage of their resources. According to Bakici, Almirall, and Wareham (2013), the smart city is "a high-tech intensive and advanced city that connects people, information and city elements using new technologies in order to create a sustainable, greener city, competitive and innovative commerce, and increased life quality". ISO TMB Smart Cities Strategic Advisory Group defined the smart city as "one that... dramatically increases the pace at which it improves its social economic and environmental (sustainability) outcomes, responding to challenges such as climate change, rapid population growth, and political and economic instability... in order to provide better services and quality of life to those in and involved with the city (residents, businesses, visitors), now and for the foreseeable future, without unfair disadvantage of others or degradation of the natural environment" (ISO, 2015). Smart cities are initiators of better economic opportunities (Clarke, 2017) and social equity and inclusion (McClellan, Jimenez and Koutitas, 2017). Urban expansion requires good policies and long-term actions for the smart environment (Fei and Zhao, 2019). The international community is completely aware of the importance of smart and sustainable cities and communities and made it one of the 17 sustainable development goals (SDGs) (Department of Economic and Social Affairs, 2019).

Accordingly, the interest in measuring the level up to which the cities embrace smart initiatives has increased. So far, two approaches have been devised. The first one is using single indicators such as the key performance indicators (KPIs) of Smart Sustainable Cities chosen by the U4SSC initiative (International Telecommunication Union, 2019). Another approach is using composite indicators; multiple indicators aggregated in a single number. Some of the composite indicators in the field identified by the European Commission are China Urban Sustainability Index, European Green City Index, and European Green Capital Award (Science for Environment Policy, 2018). However, a more comprehensive composite index which ranks cities on a global scale that attracted our attention is the UN-Habitat's City Prosperity Initiative (CPI). According to the United Nations (UN), the CPI is an approach that gives data and knowledge on urban metrics relevant for creating urban policies and action plans. It ranks cities using six indexes: Productivity index, Equity, and social inclusion index, Environmental sustainability index, Infrastructure development index, Quality of life index, and Urban governance and legislation index.

International standards are considered to be initiators of urban development, so, standard developing organizations (SDO's) have developed a series of standards 
with requirements for building components of smart city initiative (Viengkham, 2017). SDO's have embraced a number of technical standards with requirements for smart buildings, smart vehicles, smart city lighting and so on, as well as different management systems standards. Further, SDO's have developed standards that discuss smart city indicators and guidelines for smart community infrastructures (Anthopoulos, 2017). Those standards are made up of standardization and city experts from countries around the world. International standards provide the frameworks and tools which take policy-makers into the future.

The aim of the paper is to determine whether there is an impact of international standards on the development of smart regions and cities. The impact of participation in international standardization technical committees on the level up to which cities act sustainably has been previously tackled by Mijatovic, Horvat, and Maricic (2018). To conduct our research, we opted to observe the values of the CPI indexes and number of certificates related to different management systems which could initiate further development of smart and sustainable cities. Accordingly, the two hypotheses of our research are:

H1: There is a difference between the level of smart cities in different regions and the number of certificates that could initiate further development of smart and sustainable cities.

H1a: There is a difference between the number of certificates that could initiate development of smart and sustainable cities in EU and non-EU countries.

$\mathrm{H} 1 \mathrm{~b}$ : There is a difference between the level of smart cities (values of CPI) in EU and non-EU countries.

$\mathrm{H} 2$ : There is a positive impact of international standards on the development of smart regions and cities.

In order to answer the presented hypothesis we took a two-fold approach. The first direction of analysis was to use parametric tests, a nonparametric test, and correlation analysis to explore whether there are differences between regions regarding the number of employed standards and indicators which measure the city smartness. The other direction was the application of the Structural Equation Modelling (SEM) analysis to explore impact of international standards on the development of smart regions and cities. More details on the specific SEM analysis employed are given in Section 3.

The paper is structured as follows. The next section gives an overview of relevant literature related to smart regions and cities, standards and their impact on the economy and environmental development of regions and cities. The third and fourth sections present the basics of the statistical methodology as well as empirical data and analysis. The results and discussion are given in the fifth section and concluding remarks follow. 


\section{Literature review}

Standards play an essential role in the constructing and developing of cities (Steele, 2013) as well as for defining components of smart city initiative (Viengkham, 2017). In an attempt to define rules for the industry, SDOs have composed competitive standards and guidelines for corresponding solutions' development (Anthopoulos, Janssen and Weerakkody, 2016). At 2017, the International Organization for Standardization (ISO) marked the World Standards Day theme as Standards make cities smarter, to highlight the initiative and importance of applying standards for modern cities and ensure a decent quality of life for their citizens (Ruso and Filipovic, 2018; ISO, 2017a). According to the ISO (2019), certification standards that make cities sustainable and smart are management system standards for energy efficiency (ISO 50001), information security (ISO 27001), information technology services (ISO 20000-1) and environment (ISO 14001). As part of an integrated management system, ISO 9001 - quality management systems standard is always side by side with abovementioned standards (Zgodavova and Bober, 2012). ISO 9001 is a generic standard for quality management systems that makes a significant improvement to a company's performance. Liebesman (2008) suggests that the adoption of ISO 9001 contributes to reducing risk management and that this enhances various areas such as customer satisfaction, supply chain, revenue recognition, information security, logistics, and natural disaster management. Therefore, in our analysis, besides the four standards suggested by the ISO, we also decided to include ISO 9001 as another important standard for smart infrastructure development of cities.

ISO certification in EU countries grows vastly (Raweni and Majstorović, 2016), which implies more requirements for non-EU countries who export in the EU market. Namely, the application of standards increases exports to EU countries (Başaran, 2017). Asfaw, Mithöfer, and Waibel (2010) highlighted that "compliance with standards for developing countries' small-scale producers entails costly investment in variable inputs and long- term structures". Further, non-EU countries aim at deeper integration with the EU because they want to envisage "significant economic gains as common norms, rules and standards are likely to increase economic exchange with the EU" (Prange-Gstöhl, 2009, p. 5297). Moreover, Cots and Casadesús (2015) found that countries with the highest GDP are less intensive in terms of certification.

The diffusion of ISO 9001 certifications started mostly in Europe (Sampaio, Saraiva and Guimarães Rodrigues, 2009). Nowadays, Europe and East Asia and Pacific are leading continents by the number of ISO 9001 certificates (ISO, 2017). Williams (2004) highlights that the economy is one of the important motives behind the increased ISO 9001 implementation. Saraiva and Duarte (2003) emphasized the economic and societal implications of ISO 9001 at both local and global levels. In 
the top ten countries with ISO 9001 certificates, Sampaio, Saraiva and Guimarães Rodrigues (2009) found five European countries (Italy, the UK, Spain, Germany, France), two Far East countries (China, Japan), India, the USA, and Australia. By measuring a ratio of a number of ISO 9001 and ISO 14001 certificates with the population and number of companies in a country, Mikulis and Ruževičius (2009) found out that quantity of these certificates in EU-10 member states has a slight correlation with the productivity. To and Lee (2014) analysed the correlation between the number of ISO 14001 certificates and export volumes in 30 countries. They found out that there is a significant linkage between ISO 14001 adoption and international trading. The biggest number of new ISO 14001 certificates was issued in the Far East, followed by Europe and Africa/West Asia. Neumayer and Perkins (2004) found that countries that had higher shares of exports to the EU and Japan, lower shares of exports to the US and higher per capita incomes were more likely to exhibit a higher number of ISO 14001 certifications.

In recent years, a significant increase in global energy consumption has led governments and industrial institutions to deploy the smart city concept (Khatoun and Zeadally, 2016). Smart cities are sustainable cities (Vodă and Radu, 2018) that meet specific requirements and characteristics structured within efficient and sustainable policies (de Andrade et al., 2016). Khatoun and Zeadally (2016) state that one of the components of smart cities includes energy management. Karcher and Jochem (2015) highlight that this topic is particularly important for a reduction of the total global consumption within economic growth and an increasing number of users. Yuriev and Boiral (2018) say that energy management system has a positive effect on productivity and "potential to save energy, increase profitability and reduce greenhouse gas emission worldwide" (Samarakoon and Rajini, 2013, p. 210). One of the internationally recognized models for energy management is standard ISO 50001 (Jovanović, Filipović and Bakić, 2017). According to the ISO (2017), Europe has the highest and Africa the smallest number of ISO 50001 certificates. Research carried out by Jovanović and Filipović (2016) showed that in the EU region, ISO 50001 significantly reduced industrial energy use.

Information and Communication Technologies (ICTs) are regarded as agents of economic growth and a catalyst for structural economic and social change (Dameri, 2013). Hence, many cities around the world are seeking to become a smart city, using networked, digital technologies and urban big data to tackle a range of issues, such as improving governance and service delivery, creating more resilient critical infrastructure, growing the local economy, becoming more sustainable, producing better mobility, gaining transparency and accountability, enhancing quality of life, and increasing safety and security (Kitchin, 2016). In order to help organisations establish and maintain an information security management system, ISO developed ISO 27001 standard whose diffusion is underway mostly in Asia and Europe (Tunçalp, 2014). From the mid-nineties, many organizations in the 
IT sector have shown their interest in deploying best practices for implementing and managing the services provided (Mesquidaand Mas, 2015). ISO/IEC 200001 - Information technology - Service management - Part 1: Service management system requirements contains the formal specification of the standard and describes the requirements necessary to comply with to attain the certificate. According to a number of ISO 20000-1 certifications, Asia has taken over leadership (Cots and Casadesús, 2015).

The issue of measuring the impact of standardization on the level of smart cities has attracted the attention of both worldwide organizations and academics. In our literature review, we identified several different models and approaches for the cause. Giffinger et al. (2007) suggested six main components for measuring the development of smart cities: smart economy, smart people, smart governance, smart mobility, smart environment, and smart living. ISO published ISO 37120 that defines and establishes methodologies for a set of indicators to steer and measure the performance of city services and quality of life. Moreover, Neirotti et al. (2014) defined seven smart city domains, while Lee, Hancock and Hu (2014) suggested a framework for smart city analysis with six dimensions. Bonaiuto et al. (2015) compared cross-cultural tools such as CPI, Perceived Residential Environment Quality Indicators, Neighbourhood Attachment Scale and items for measurement of Residential Satisfaction to validate them. They stated that CPI addresses more than just economic growth and concluded that it could be considered a mainly objective tool to assess the quality of life. Further, by recalculating CPI dimensions according to the contextual situation of Tehran Metropolis in Iran, Arbab (2017) indicated different importance and preference between the CPI's six dimensions and twenty-two sub-dimensions instead of the equal weight in the original model. By measuring, analysing and prioritizing the urban areas of Ahvaz including CPI dimensions, Safaee Pour et al. (2017) came to the same conclusion.

"A smart city is one whose economy is increasingly driven by technically inspired innovation, creativity and entrepreneurship" (Kitchin, 2014, p. 131). Moreover, the smart city industry plays a key role in the sustainable city and the growth of the national economy (Kim, Jung and Choi, 2016). However, the economy is the major driver of smart city initiatives (Chourabi et al. 2012). Actually, a challenge for smart cities is to maintain economic growth and improve the quality of life at the same time (Nam and Pardo, 2011).

There is a limited number of publications written about the economic effects of standardisation (Trajković and Milosević, 2016, Blind, 2004 and Saraiva and Duarte, 2003), although this topic has recently given the notable attention. Blind (2004) investigated the effect on macroeconomic growth in the new economy, where formal standards are a very important source of codified and publicly available knowledge, while Saraiva and Duarte (2003) highlighted the economic implications of international standards. On the same topic, Trajković and Milosević 
(2016) confirmed the positive relationship between innovative effects and the economic effects of standardization. Further, SDO's such as German Institute for Standardization, Association Française de Normalisation, and ISO have provided different analyses of the economic benefits of standardisation as well as different methodologies among which ISO methodology 2 is the widely recognized.

According to the literature review, we acknowledged that standards could be frameworks for the development of smart and sustainable cities and regions, and further to have an influence on the economy and environment. For measuring the level of the city's smartness there have been developed different indicators and initiatives. We chose UN-Habitat's CPI initiative because of its relevance and availability of data. There is a lack of research with empirical evidence on the impact of international standards on the level of smart regions and cities, so with this research, we strive to fulfil this literature gap.

\section{Methodology}

In our research, we aimed to determine whether international standards influence the development of smart regions and cities. We observed the data from publicly available ISO (2017) to analyse how different countries practiced standardization by a number of different certificates (ISO 9001, ISO 14001, ISO 27001, ISO 50001, and ISO 20000-1). Further, we explored the association between the level of smart cities in different regions and the number of certificates that could initiate further development of smart and sustainable cities. Especially, we observed two regions, the $19 \mathrm{EU}$ countries, and 24 non-EU countries. For a measure of the level of smartness, we used UN-Habitat's City Prosperity Initiative (CPI). The aim of CPI is the measurement of urban prosperity conceptualized into six dimensions: Productivity, Infrastructure Development, Quality of Life, Equity and Social Inclusion, Environmental Sustainability, and Urban Governance and Legislation.

The chosen multivariate data analysis employed in an attempt to answer the research questions was the structural equation modeling (SEM). The SEM analysis gained in popularity as it lies on principles of factor analysis and regression or path analysis (Stein, Morris and Nock, 2012). On one side, it can reduce the dimensionality of the observed phenomenon, while at the same time, it provides information on the relationship between the newly formed, latent, variables or constructs. Due to the above-stated benefits, the SEM analysis became a commonly used statistical analysis for the evaluation of the plausibility of a hypothesized model (Guarino, 2004).

The SEM analysis has been used with success in the field of exploring smart cities and regions. For example, in a recent study Picatoste et al. (2018) used SEM to explore how information and communication technologies (ICTs) skills impact 
youth employability in the context of smart cities. Next, Romão et al. (2018) through SEM observed the determinants of urban attractiveness of smart cities. While Sepasgozar et al. (2019)analysed the factors which might influence the acceptance of urban technologies in developing smart cities. Again To, Lee and Lam (2018) applied structural modeling to observe the professionals' intention to use smart and sustainable building technologies. It can be concluded that the SEM analysis has been performed with success in the field of smart cities.

One of the issues we were facing prior to conducting SEM analysis was the small sample. Namely, the covariance-based SEM (CB-SEM) analyses most commonly used in business and marketing research requires strict assumptions to be fulfilled, such as multivariate normality of data and minimum sample size above 300 (Diamantopoulos and Siguaw, 2000). As these requirements are sometimes difficult to meet (as in our case), in the last decade a non-parametric SEM approach has been proposed: the partial least squares SEM (PLS-SEM) (Hair, Ringle, and Sarstedt, 2011). The main benefit of the PLS-SEM over CB-SEM is that when some of the CB-SEM assumptions are violated, the PLS-SEM often produces more robust estimations of path coefficients (Ringle and Schlittgen, 2007; Reinartz, Haenlein and Henseler, 2009). The PLS-SEM can be observed as the non-parametric alternative to the CB-SEM. Accordingly, herein we conducted the PLS-SEM using the SmartPLS 3 software.

To explore the influence of international standards on the smartness of the regions we grouped these dimensions into two constructs: Economy and Environment. As the sample size rule of the thumb for the PLS-SEM is 10 times the max number of variables that make the latent variable (Hair, Ringle, and Sarstedt, 2011) and as we have 43 countries, we had to modify the construct Standards. Namely, we removed the ISO 50001 as it is an environmental standard, such as the ISO 14001 which we include. Prior to diving the CPI dimensions into constructs, we conducted a correlation analysis between them. The correlation analysis showed that there is no statistically significant correlation between Urban governance and legislation index and the rest of the dimensions. Therefore, we decided to exclude it from the SEM analysis as it might decrease the quality of the results. Construct Economy consists of Productivity index, Quality of life index and Equity and social inclusion index. The construct Environment consists of Quality of life index, Infrastructure development index, and Environmental sustainability index. The data for each of the above-mentioned indexes comes from the UN-Habitat's City Prosperity Initiative (CPI) for the year 2015. Figure 1 presents our conceptual model. 
Figure 1: Conceptual model

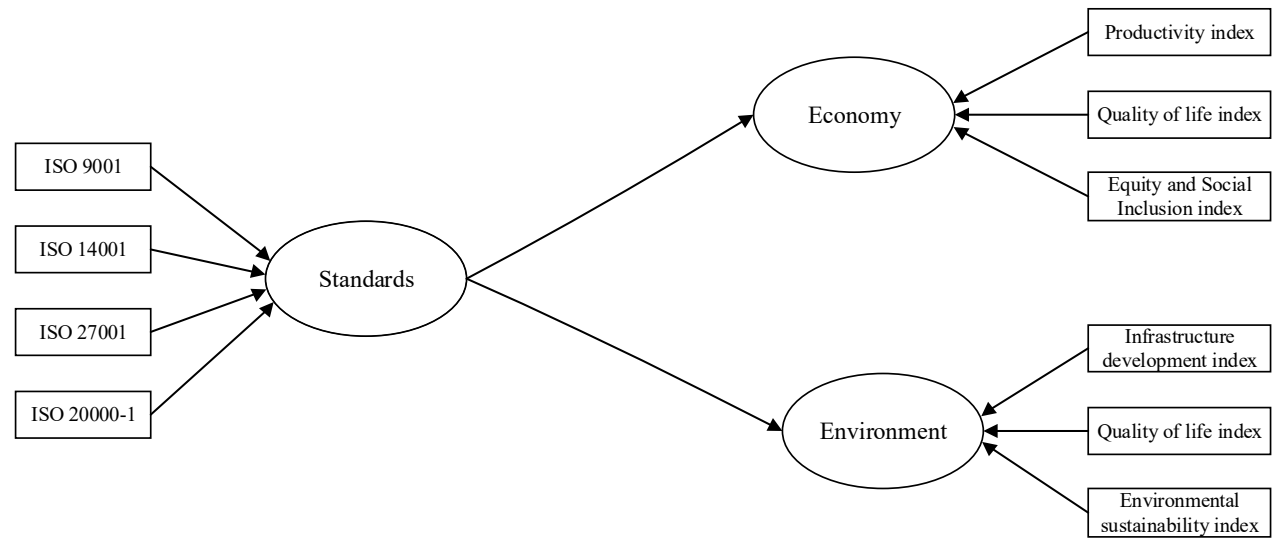

Another benefit of the application of the PLS-SEM is the possibility of conducting the estimation of path coefficients using bootstrap. Namely, the bootstrap builds upon the idea of using resampling and conducting the analysis on each of the resamples (Efron and Tibshirani, 1993). In PLS-SEM bootstrap, the significance of the PLS coefficients is obtained. However, bootstrap significance and traditional significance are not the same. "For bootstrapped significance, a probability level of .05 means there is one chance in 20 that a result as strong or stronger in absolute terms will occur due to chance of sampling (taking another sample from the data)" (Garson, 2016). Herein, we conducted the percentile bootstrap as our sample was below 50 (Garson, 2016) with 5000 samples.

\section{Empirical data and analysis}

\subsection{Characteristics of the cities covered with the research in regard to the number of certificates}

Our sample consists of 43 countries that have at least one city ranked on the CPI. To create the dataset on which the study was conducted we integrated the official CPI data set and the official ISO data regarding the number of introduced standards. However, the CPI data is given per city, while the data provided by ISO is given per country. Therefore, to obtain the CPI data per country, we used the mean value of the cities' indicator values.

Out of the 43 countries, 19 are from the EU, while the rest are non-EU. First, we set to compare whether there are differences in the number of certificates to introduced standards between the two groups of countries. Prior to comparison, the values of the indicators have been scaled from 0 to 100 using the distance to a reference 
country method (Nardo et al., 2005). To compare the two groups we conducted the Mann-Whitney (MW) test as the number of certificates is not normally distributed. Namely, the significance of the Kolmogorov-Smirnov test was below 0.01 in all five cases. Interestingly, the MW test showed a statistically significant difference in all cases, except when it comes to ISO 20000-1 (Table 1).

Table 1: Parameter values of five chosen standards for different regions and, the significance of the MW-test

\begin{tabular}{|c|c|c|c|c|}
\hline Standard & Region & MW & Mean & Median \\
\hline \multirow{2}{*}{ ISO 9001} & EU & \multirow{2}{*}{$-1.981 *$} & 6.626 & 2.540 \\
\hline & Non-EU & & 6.590 & 0.954 \\
\hline \multirow{2}{*}{ ISO 14001} & EU & \multirow{2}{*}{$-2.372 *$} & 4.380 & 2.142 \\
\hline & Non-EU & & 6.131 & 0.694 \\
\hline \multirow{2}{*}{ ISO 27001} & EU & \multirow{2}{*}{$-2.789 * *$} & 5.142 & 1.699 \\
\hline & Non-EU & & 6.128 & 0.370 \\
\hline \multirow{2}{*}{ ISO 50001} & EU & \multirow{2}{*}{-4.564} & 8.603 & 1.230 \\
\hline & Non-EU & & 0.475 & 0.059 \\
\hline \multirow{2}{*}{ ISO $20000-1$} & EU & \multirow{2}{*}{-1.790} & 15.771 & 5.685 \\
\hline & Non-EU & & 13.573 & 1.839 \\
\hline
\end{tabular}

$* \mathrm{p}<0.05, * * \mathrm{p}<0.01$

When it comes to the ISO 9001 standard, there is a statistically significant difference. The medians of the two groups differ visibly, but the EU countries have, on average, slightly more certificates issued. Contrarily, the non-EU countries have more imposed ISO 14001 and ISO 27001. The greatest mean difference can be observed for the ISO 50001: the mean in the EU is 8.603, while in the non-EU it is 0.475 . Although the medians of ISO 20000-1 differ, the difference is not statistically significant.

In the next step, we observed the differences between the two groups for the values of the CPI dimensions. The KS test showed that Productivity index, Equity and social inclusion index, and Environmental sustainability index are normally distributed ( $p>0.05)$, while the rest are not. Therefore, to explore the differences we used t-test and MW test depending on the observed dimension. As it can be observed in Table 2, the dimension values are statistically higher in EU than in non-EU countries except for the Urban governance index for which no statistically significant difference was measured. The highest mean difference was for the dimension Infrastructure development index (28.855), followed by Quality of life index (22.103). 
Jelena Ruso, Ana Horvat, Milica Maričić • Do international standards influence...

Table 2: Parameter values of CPI dimensions for different regions, the significance of the t-test and MW-test, and the means per region

\begin{tabular}{|c|c|c|c|c|}
\hline Dimension & Region & t-test & MW & Mean \\
\hline \multirow{2}{*}{ Productivity index } & EU & \multirow{2}{*}{$2.179 *$} & \multirow{2}{*}{ / } & 62.469 \\
\hline & Non-EU & & & 52.681 \\
\hline \multirow{2}{*}{ Equity and social inclusion index } & EU & \multirow{2}{*}{$6.006^{* *}$} & \multirow{2}{*}{ / } & 83.443 \\
\hline & Non-EU & & & 66.896 \\
\hline \multirow{2}{*}{ Environmental sustainability index } & EU & \multirow{2}{*}{$2.999 * *$} & \multirow{2}{*}{1} & 62.363 \\
\hline & Non-EU & & & 43.764 \\
\hline \multirow{2}{*}{ Infrastructure development index } & EU & \multirow{2}{*}{ / } & \multirow{2}{*}{$-5.331 * *$} & 84.605 \\
\hline & Non-EU & & & 55.750 \\
\hline \multirow{2}{*}{ Quality of life index } & EU & \multirow{2}{*}{ / } & \multirow{2}{*}{$-4.426 * *$} & 90.819 \\
\hline & Non-EU & & & 68.716 \\
\hline \multirow{2}{*}{ Urban governance and legislation index } & EU & \multirow{2}{*}{ / } & \multirow{2}{*}{-1.101} & 68.082 \\
\hline & Non-EU & & & 60.993 \\
\hline
\end{tabular}

$* \mathrm{p}<0.05, * * \mathrm{p}<0.01$

In the next step, we wanted to explore whether there is an effect of standards on the values of the CPI dimensions. Additionally, we took into account the observed regions. Namely, we conducted a correlation analysis per region. The correlation analysis for the EU region is given in Table 3. Interestingly, there are just three statistically significant coefficients: between ISO 14001 and Quality of life index (0.502), ISO 50001 and Quality of life index (0.500), and ISO 27001 and Environmental sustainability life index (-0.535). The three coefficients are mediumstrong. The relation is such that if the ISO 14001 and ISO 50001 increase, the value of the Quality of life index will increase.

Table 3: Spearman's correlation coefficient between the five standards and the six CPI dimensions (EU region)

\begin{tabular}{|l|c|c|c|c|c|c|}
\hline & $\begin{array}{c}\text { Productivity } \\
\text { index }\end{array}$ & $\begin{array}{c}\text { Infrastructure } \\
\text { development } \\
\text { index }\end{array}$ & $\begin{array}{c}\text { Quality } \\
\text { of life } \\
\text { index }\end{array}$ & $\begin{array}{c}\text { Equity } \\
\text { and social } \\
\text { inclusion } \\
\text { index }\end{array}$ & $\begin{array}{c}\text { Environmental } \\
\text { sustainability } \\
\text { index }\end{array}$ & $\begin{array}{c}\text { Urban } \\
\text { governance } \\
\text { and } \\
\text { legislation } \\
\text { index }\end{array}$ \\
\hline ISO 9001 & -0.111 & -0.174 & 0.335 & -0.089 & -0.175 & -0.218 \\
\hline ISO 14001 & 0.137 & 0.047 & $0.502^{*}$ & 0.086 & -0.098 & -0.025 \\
\hline ISO 27001 & -0.211 & -0.384 & 0.154 & -0.074 & $-0.535^{*}$ & -0.260 \\
\hline ISO 50001 & -0.212 & -0.119 & $0.500^{*}$ & -0.223 & -0.125 & 0.011 \\
\hline ISO 20000-1 & -0.061 & -0.085 & 0.331 & 0.066 & -0.154 & -0.349 \\
\hline
\end{tabular}


The correlation analysis for the non-EU region is given in Table 4. Interestingly, there are more statistically significant coefficients than in the case of the EU region and they are significant on a higher level. Our findings show that standards have an impact on the Productivity index, Infrastructure development index, and Quality of life index and the relation is such that more standards lead to higher values of the dimensions. Also, the Equity and social inclusion index is affected with ISO 14001, ISO 27001, and ISO 50001. The highest measured correlation coefficient is between ISO 9001 and Infrastructure development index (0.756), followed by the correlation between ISO 9001 and Quality of life index (0.740).

Table 4: Spearman's correlation coefficient between the five standards and the six CPI dimensions (non-EU region)

\begin{tabular}{|l|c|c|c|c|c|c|}
\hline & $\begin{array}{c}\text { Productivity } \\
\text { index }\end{array}$ & $\begin{array}{c}\text { Infrastructure } \\
\text { development } \\
\text { index }\end{array}$ & $\begin{array}{c}\text { Quality of } \\
\text { life index }\end{array}$ & $\begin{array}{c}\text { Equity } \\
\text { and social } \\
\text { inclusion } \\
\text { index }\end{array}$ & $\begin{array}{c}\text { Environmental } \\
\text { sustainability } \\
\text { index }\end{array}$ & $\begin{array}{c}\text { Urban } \\
\text { governance } \\
\text { and } \\
\text { legislation } \\
\text { index }\end{array}$ \\
\hline ISO 9001 & $0.614^{* *}$ & $0.756^{* *}$ & $0.740^{* *}$ & 0.401 & 0.277 & -0.088 \\
\hline ISO 14001 & $0.611^{* *}$ & $0.681^{* *}$ & $0.734^{* *}$ & $0.411^{*}$ & 0.208 & -0.107 \\
\hline ISO 27001 & $0.627^{* *}$ & $0.663^{* *}$ & $0.699^{* *}$ & $0.535^{* *}$ & 0.200 & -0.185 \\
\hline ISO 50001 & $0.717^{* *}$ & $0.641^{* *}$ & $0.721^{* *}$ & $0.486^{*}$ & 0.239 & -0.106 \\
\hline ISO 20000-1 & $0.565^{* *}$ & $0.639^{* *}$ & $0.627^{* *}$ & 0.383 & 0.152 & -0.203 \\
\hline
\end{tabular}

${ }^{*} \mathrm{p}<0.05, * * \mathrm{p}<0.01$

\subsection{Application of SEM analysis}

The next step of our analysis was the application of the SEM analysis. The first related output presented is the variance inflation factor (VIF). Namely, the VIF indicates the presence of multicollinearity within the latent variable in a formative model. VIF is the most commonly used metric for inspection of multicollinearity. The cutoff for VIF is 5 (Hair, Ringle, and Sarstedt, 2011). As can be observed from Table 5, some constructs have the VIF above 5. The construct which draws attention is the construct Standards where two indicators have high VIF - ISO 9001 and ISO 14001. In a way, this is an expected result having in mind that ISO 9001 and ISO 14001 applied together contribute to corporate sustainability (Ferreira, Poltronieri, and Gerolamo, 2019). Although multicollinearity was detected, we decided to use both indicators in the construct as the PLS estimation shows a very good robustness even in the more extreme cases of multicollinearity (Westlund, Källström, and Parmler, 2008). 
Jelena Ruso, Ana Horvat, Milica Maričić • Do international standards influence...

Table 5: Obtained VIF per construct

\begin{tabular}{|c|c|l|c|l|c|}
\hline \multicolumn{5}{|c|}{ Construct } & \multicolumn{2}{c|}{ Environment } \\
\hline Standards & \multicolumn{2}{c|}{ Economy } & \multicolumn{1}{c|}{ Indicator } & Indicator \\
\hline Indicator & VIF & \multicolumn{1}{|c|}{ Indicator } & VIF & $\begin{array}{l}\text { Infrastructure } \\
\text { development index }\end{array}$ & 4.999 \\
\hline ISO 9001 & 14.934 & Productivity index & 2.093 & 5.030 \\
\hline ISO 14001 & 15.154 & Quality of life index & 3.085 & Quality of life index & 1.174 \\
\hline ISO 27001 & 2.695 & $\begin{array}{l}\text { Equity and social } \\
\text { inclusion index }\end{array}$ & 2.780 & $\begin{array}{l}\text { Environmental } \\
\text { sustainability index }\end{array}$ & \\
\hline ISO 20000-1 & 3.116 & & & & \\
\hline
\end{tabular}

Next, we provide the results on the outer model (Table 6). When it comes to the construct Standards and Economy, it can be observed that all coefficients (outer weights) are positive, high and statistically significant meaning that the constructs are stable and well-constructed. However, the results indicate that within the construct Environment indicator Environmental sustainability index is not statistically significant with a coefficient of 0.305 and value of $t$ statistics of 1.287. This could indicate that the structure of this construct could be more closely explored in future research.

Table 6: Obtained outer weights (Outer model)

\begin{tabular}{|c|l|c|c|c|c|}
\hline \multirow{2}{*}{ Construct } & \multicolumn{1}{|c|}{ Indicator } & $\begin{array}{c}\text { Original } \\
\text { sample }\end{array}$ & $\begin{array}{c}\text { Sample } \\
\text { mean }\end{array}$ & StD & T statistics \\
\hline \multirow{5}{*}{ Standards } & ISO9001 & 0.769 & 0.823 & 0.074 & $10.405^{* *}$ \\
\cline { 2 - 6 } & ISO14001 & 0.798 & 0.871 & 0.088 & $9.111^{* *}$ \\
\cline { 2 - 6 } & ISO27001 & 0.812 & 0.870 & 0.057 & $14.290^{* *}$ \\
\cline { 2 - 6 } & ISO20000-1 & 0.907 & 0.909 & 0.040 & $22.691^{* *}$ \\
\hline \multirow{3}{*}{ Economy } & Productivity index & 0.891 & 0.879 & 0.060 & $14.941^{* *}$ \\
\cline { 2 - 7 } & Quality of life index & 0.929 & 0.929 & 0.033 & $27.736^{* *}$ \\
\cline { 2 - 7 } & Equity and social inclusion index & 0.873 & 0.866 & 0.076 & $11.479^{* *}$ \\
\hline \multirow{3}{*}{ Environment } & Infrastructure development index & 0.960 & 0.941 & 0.094 & $10.258^{* *}$ \\
\cline { 2 - 7 } & Quality of life index & 0.978 & 0.960 & 0.094 & $10.450^{* *}$ \\
\cline { 2 - 6 } & Environmental sustainability index & 0.305 & 0.302 & 0.237 & 1.287 \\
\hline
\end{tabular}

Next, we focus on the obtained path coefficients in the inner model, the model between latent variables (Table 7). Standards have a positive impact on both the Economy (0.338) and Environment (0.325). The relationship is such that if the Standards increase the values of the latent constructs are going to increase for 0.338 and 0.325 respectively. The slightly higher standard deviation of the coefficient between Standards and Environment draws attention and indicates that this impact 
has varied more in the 5000 resamples. The $\mathrm{T}$ statistics is statistically significant meaning that the impact is statistically significant.

Table 7: Obtained paths (Inner model)

\begin{tabular}{|l|c|c|c|c|}
\hline \multicolumn{1}{|c|}{ Construct } & $\begin{array}{c}\text { Original } \\
\text { sample }\end{array}$ & Sample mean & StD & T statistics \\
\hline Standards $\rightarrow$ Economy & 0.338 & 0.380 & 0.069 & $4.863^{* *}$ \\
\hline Standards $\rightarrow$ Environment & 0.325 & 0.368 & 0.084 & $3.844 * *$ \\
\hline
\end{tabular}

The distribution of the paths after 5000 resamples is given in Figure 2. Looking at the distribution of the path Standards $\rightarrow$ Economy we can observe that the values of the coefficients were positive throughout the iterations. On the other hand, the same does not account for Standards $\rightarrow$ Environment as there were iterations when that impact was negative.

Figure 2: Distribution of the path coefficients
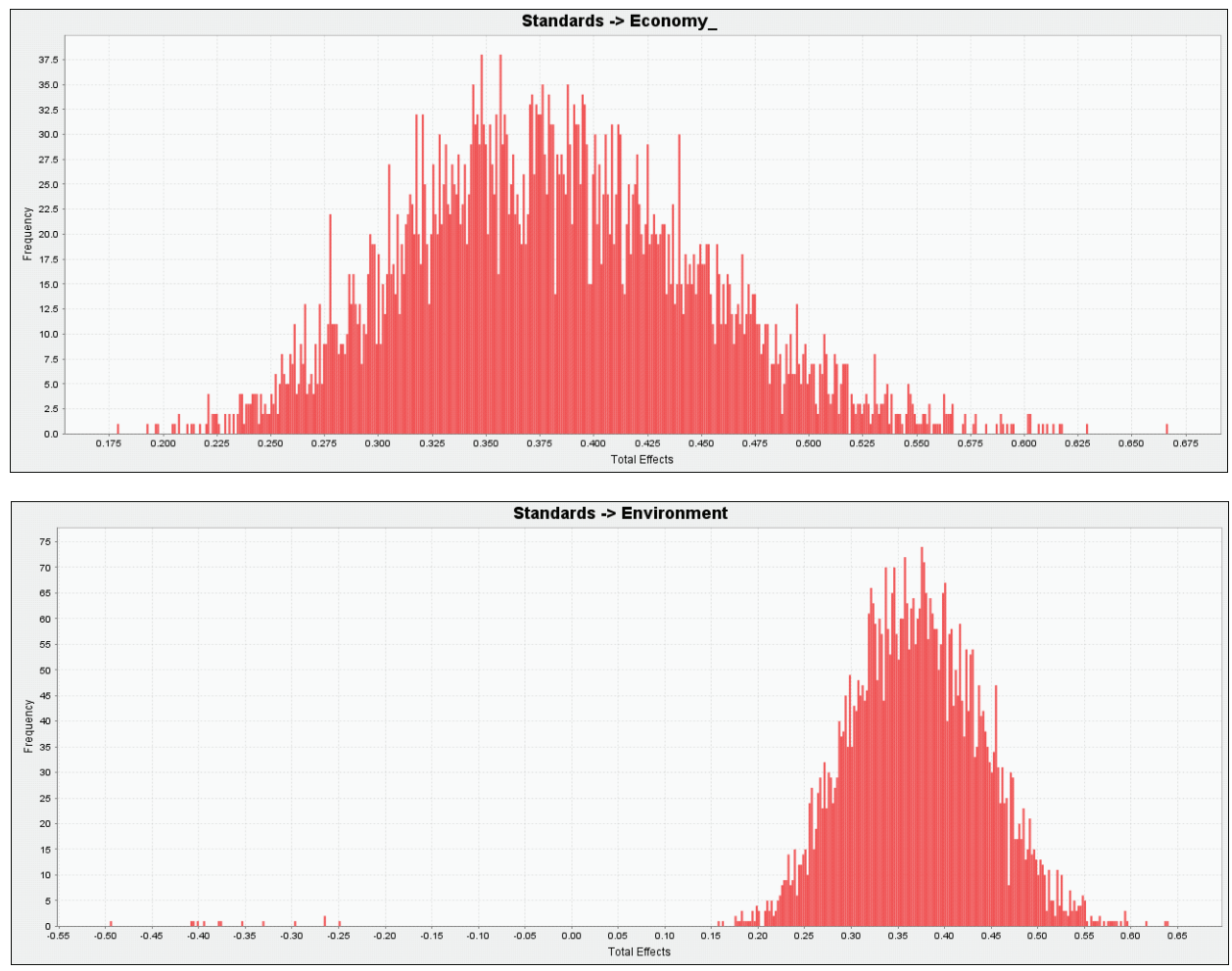
Finally, we observe the coefficient of determination which denotes up to which percent is the variability of one latent variable explained using the values of other variables that have an impact on it. In the case of the construct Economy, the coefficient of determination of the original sample is 0.114 , with a mean of 0.149 and StD $0.054(\mathrm{t}=2.098, \mathrm{p}<0.01)$. We observe that the Standards explain $11.4 \%$ of Economy, while the bootstrap average is $14.9 \%$. Looking at the Environment, the coefficient of determination of the original sample is 0.105 , with a mean of 0.143 and StD $0.054(\mathrm{t}=1.957, \mathrm{p}<0.05)$. We observe that the Standards explain $10.5 \%$ of Environment, while the bootstrap average is $14.3 \%$. We can conclude that the models are not high explanatory quality, that more factors except standards could be taken into account, and that the model of Economyhas better quality. Even though, our research provides enough evidence on international standards impact on the development of smart regions and cities.

\section{Results and discussion}

Our findings show that when it comes to the ISO 9001standard, there is a statistically significant difference. The EU countries have, on average, slightly more certificates issued. ISO 9001 is the most frequently introduced standard in companies, and it has been the foundation for the implementation of other management systems standards (Kafel and Casadesus, 2016). Moreover, motivation factors for ISO 9001 certification could be improved company image and competitiveness (Iatridis and Kesidou, 2017), especially for recent EU member countries (Georgiev and Georgiev, 2015). Contrarily, the non-EU countries have more imposed ISO 14001 and ISO 27001, as standards in specific sectors. When it comes to a difference between the values of CPI in EU and non-EU countries results showed that the dimension values are statistically higher in the EU than in non-EU countries.

Our next result is related to whether there is an effect of standards on the values of the CPI dimensions. The correlation analysis for the EU region shows that there are just three statistically significant coefficients. The relation is such that if the ISO 14001 and ISO 50001 increase, the value of the Quality of life index will increase. Economic development has long been considered the best predictor of quality of life (Bonaiuto et al., 2015), as well as competitiveness (Grilo and Koopman, 2006).

The correlation analysis for the non-EU region showed that there are more statistically significant coefficients than in the case of the EU region. Namely, previous studies acknowledged that standards have an important role in the development of regions and cities, especially for countries in transition (Swinnen et al., 2015), and that countries use standards to build infrastructure for economic development (Watson and Krislov, 2006; Loconto and Busch, 2010). Accordingly, 
policymakers recognized international standards as an important factor for the competitiveness of their economies (Blind and Mangelsdorf, 2016). Our findings show that standards have an impact on the Productivity index, Infrastructure development index, and Quality of life index and the relation is such that more standards lead to higher values of the dimensions. Also, the Equity and social inclusion index is affected with ISO 14001, ISO 27001, and ISO 50001.The reason for this could be that companies in transition countries tend to use standards as sources for acquiring external knowledge (Zahra and George, 2002). Further, it should be noted that no standard imposed in the non-EU region has an effect on the environmental and legislative aspects.

Finally, the results of the SEM analysis indicate that the number of issued certificates of the selected standards has a statistically significant impact on both Economy and Environmental constructs. The result is in line with Caragliu and Del Bo (2019) who showed that smart city policies have a positive influence on economic growth. Also, the results show that the standardization explains more than $10 \%$ of both Economy and Environmental constructs. Having in mind that the number of issued certificates is the only predictor of the two constructs, we can say that the models are of satisfactory quality.

\section{Conclusions}

Motivated with the aim to explore the impact of international standards on the development of smart regions and cities, this paper assesses the relationship between the number of certificates and values of CPI dimensions. By authors' knowledge, this paper is the first attempt to explore the impact of standards on the development of smart regions and cities and to give empirical evidence on it. The findings indicate that international standards could be fundamentals for national policies regarding smart regions and cities.

There is a statistically significant difference between regions when it comes to the effects of standards on the values of the CPI dimensions. Our findings show that standards have an impact on CPI dimensions and that this impact is more significant in non-EU countries, which confirmed our assumption H1. Reasons for this could be found in trends of transition countries to acquire new knowledge from the certification process. Further, this implies that countries could use models given in international standards for making governmental policies to develop their economies. Accordingly, the results give new insights into the differences among regions in a number of certificates which could initiate further development of smart and sustainable cities. Namely, our assumption H1a is confirmed, with enough empirical evidence on a slightly more number of certificates on ISO 9001 imposed by EU countries, while the non-EU countries have more imposed 
ISO 14001 and ISO 27001. Further, the findings indicated that dimension values of CPI are statistically higher in EU than in non-EU countries, which have confirmed assumption $\mathrm{H} 1 \mathrm{~b}$. The assumption $\mathrm{H} 2$ about existing a positive impact of international standards on the development of smart regions and cities is also confirmed. This gives new insights into the understanding of benefits on international standards for the development of smart regions and cities. Therefore, international standards should be acknowledged as an influential factor, and employed in the development of policies for smart regions and cities. Defining a comprehensive "smart city vision" can be an important step in achieving greater policy region integration. The results can be beneficial for entrepreneurs or organizations that intend to apply any of the standards for smart and sustainable cities.

Limitations of this study are secondary used data that have been publicly available, while yet maybe some other significant variables can more soundly contribute to the grouping of countries based on other smart and sustainable city indicators. Due to the lack of data, some countries were excluded from the analysis. For instance, we had found data on a number of certificates but not for CPI and vice versa. Consequently, for the analysis, we used an available source of data from 2015. For future research, by following a set of Standard Indicators for City Services and Quality of Life (ISO 37120:2018), it would be valuable to employ the triangulation methodology. Namely, in order to obtain a better analysis of the variables and their correlation, a questionnaire to gather information from citizens and companies can be carried out. Finally, additional predictors besides number of issues certificates could be included in the model so as to increase the predictive power of the model.

\section{References}

Anthopoulos, L., Janssen, M., Weerakkody, V. (2016) "Smart service portfolios: Do the cities follow standards?". In Proceedings of the 25th International Conference Companion on World Wide Web, 11-15 April, Québec: International World Wide Web Conferences Steering Committee.

Anthopoulos, L. G. (2017) “The Smart City in Practice". In Understanding Smart Cities: A Tool for Smart Government or an Industrial Trick?, Cham: Springer International Publishing AG, http://doi.org/10.1007/978-3-319-57015-0.

Arbab, P. (2017) "City Prosperity Initiative Index: Using AHP Method to Recalculate the Weights of Dimensions and Sub-Dimensions in Reference to Tehran Metropolis", European Journal of Sustainable Development, Vol. 6, No. 4, pp. 289-301, http://doi.org/10.14207/ejsd.2017.v6n4p289.

Asfaw, S., Mithöfer, D., Waibel, H. (2010) "What impact are EU supermarket standards having on developing countries' export of high-value horticultural products? 
Evidence from Kenya", Journal of International Food \& Agribusiness Marketing, Vol. 22, No. 3-4, pp. 252-276, http://doi.org/10.1080/08974431003641398.

Bakici, T., Almirall, E., Wareham, J. (2013) "A Smart City Initiative: The Case of Barcelona”, Journal of the Knowledge Economy, Vol. 4, No. 2, pp. 135-148, http://doi.org/10.1007/s13132-012-0084-9.

Başaran, B. (2017) "The effect of ISO quality management system standards on industrial property rights in Turkey", World Patent Information, Vol. 45, pp. 33-46, http://doi.org/10.1016/j.wpi.2016.03.002.

Blind, K., Mangelsdorf, A. (2016) "Motives to standardize: Empirical evidence from Germany", Technovation. Vol. 48-49, pp. 13-24, http://doi.org/10.1016/j. technovation.2016.01.001.

Blind, K. (2004) The economics of standards, theory, evidence, policy. Edward Elgar. Retrieved from http://www.e-elgar.com/shop/the-economics-of-standards.

Bonaiuto, M. et al. (2015) "Perceived residential environment quality indicators (PREQIs) relevance for UN-HABITAT city prosperity index (CPI)", Habitat International, Vol. 45, pp. 53-63, http://doi.org/10.1016/j.habitatint.2014.06.015.

Caragliu, A., Del Bo, C. F. (2019) "Smart innovative cities: The impact of Smart City policies on urban innovation", Technological Forecasting and Social Change. http://doi.org/10.1016/j.techfore.2018.07.022.

Chourabi, H. et al. (2012), "Understanding smart cities: An integrative framework". In 2012 45th Hawaii international conference on system sciences (pp. 22892297). IEEE.

Clarke, R. Y. (2017) Measuring success in the development of smart and sustainable cities. In Managing for Social Impact (pp. 239-254), Cham: Springer.

Cots, S., Casadesús, M. (2015) "Exploring the service management standard ISO 20000", Total Quality Management \& Business Excellence, Vol. 26, No. 5-6, pp. 515-533, http://doi.org/10.1080/14783363.2013.856544.

Dameri, R. P. (2013) "Searching for smart city definition: a comprehensive proposal”, International Journal of Computers \& Technology, Vol. 11, No. 5, pp. 2544-2551, http://doi.org/10.24297/ijct.v11i5.1142.

de Andrade, J. B. S. O. et al. (2016) "The adoption of strategies for sustainable cities: A comparative study between Newcastle and Florianópolis focused on urban mobility", Journal of Cleaner Production, Vol. 113, pp. 681-694, http:// doi.org/10.1016/j.jclepro.2015.07.135.

Department of Economic and Social Affairs (2019) "17 goals to transform the world for persons with disabilities", New York: United Nations Secretariat. Available at: $<$ https://www.un.org/development/desa/disabilities/envision2030. html> [Accessed: May 29, 2019]

Diamantopoulos, A., Siguaw, J. A. (2000) Introducing LISREL, Thousand Oaks, CA: Sage. 
Efron, B., Tibshirani, R. (1993) An introduction to the bootstrap. Chapman \& Hall/ CRC.

Fei, W., Zhao, S. (2019) "Urban land expansion in China's six megacities from 1978 to 2015", Science of the Total Environment, Vol. 664, pp. 60-71, http:// doi.org/10.1016/j.scitotenv.2019.02.008.10.1016/j.scitotenv.2019.02.008.

Ferreira, C. S., Poltronieri, C. F., Gerolamo, M. C. (2019)"ISO 14001:2015 and ISO 9001:2015:analyse the relationship between these management systems standards and corporate sustainability",Gestão \& Produção, Vol. 26, No. 4, e3906, http://doi.org/10.1590/0104-530X3906-19.

Garson, D. (2016) Partial least squares: Regression and structural equaiton models, G. David Garson and Statistical Associates Publishing.

Georgiev, S., Georgiev, E. (2015) "Motivational factors for the adoption of ISO 9001 standards in Eastern Europe: The case of Bulgaria", Journal of Industrial Engineering and Management, Vol. 8, No. 3, pp. 1020-1050, http://doi. org/10.3926/jiem.1355.7.

Giffinger, R. et al. (2007) "Smart Cities: Ranking of European Medium-Sized Cities", Vienna, Austria: Centre of Regional Science (SRF), Vienna University of Technology.

Grilo, I., Koopman, G. J. (2006) "Productivity and microeconomic reforms: Strengthening EU competitiveness", Journal of Industry, Competition and Trade, Vol. 2, No. 6, pp. 67-84, http://doi.org/10.1007/s10842-006-9472-9.

Guarino, J. (2004) "A Comparison of First and Second Generation Multivariate Analyses: Canonical Correlation Analysis and Structural Equation Modeling", Florida Journal of Educational Research, Vol. 42, pp. 22-40.

Hair, J. F., Ringle, C. M., Sarstedt, M. (2011) "PLS-SEM: Indeed a Silver Bullet", Journal of Marketing Theory and Practice, Vol. 19. No. 2, pp. 139-152, http:// doi.org/10.2753/MTP1069-6679190202.

Iatridis, K., Kesidou, E. (2017) "What Drives the Quality of Certifiable Management System Standards Implementation? Insights from the ISO 9001 Standard", pp. 17-38, http://doi.org/10.1007/978-3-319-65675-5_2.

International Telecommunication Union (2019) Collection Methodology for Key Performance Indicators for Smart Sustainable Cities, Geneva: International Telecommunication Union.Available at: <https://www.unece.org/fileadmin/ $\mathrm{DAM} / \mathrm{hlm} /$ documents/Publications/U4SSC-CollectionMethodology forKPIfoSSC-2017.pdf> [Accessed: May 28, 2019].

ISO (2015) Smart cities Preliminary Report 2014, Switzerland. Available at: $<$ http://www.iso.org/iso/smart_cities_report-jtc1.pdf $>$ [Accessed: November $12,2019]$.

ISO (2017) The ISO Survey of Management System Standard Certifications - 2017 - Explanatory Note, Geneva: ISO Central Secretariat. Available at: <https:// 
isotc.iso.org/livelink/livelink?func=11\&objId=18808772\&objAction=browse\&v iewType $=1>$ [Accessed: May 29, 2019].

ISO (2017a) Standards make cities smarter, Geneva: World Standards Cooperation.

Available at: https://www.worldstandardscooperation.org/world-standards-day/ world-standards-day-2017/.

ISO (2019) Standards make cities sustainable. Available at: <https://pbs.twimg. com/media/CwGtiD8XEAAFN1S.jpg> [Accessed: May 30, 2019].

Jovanović, B., Filipović, J., Bakić, V. (2017) "Energy management system implementation in Serbian manufacturing-Plan-Do-Check-Act cycle approach", Journal of Cleaner Production, Vol. 162, pp. 1144-1156, http://doi.org/10.1016/j. jclepro.2017.06.140.

Jovanović, B., Filipović, J. (2016) "ISO 50001 standard-based energy management maturity model-proposal and validation in industry", Journal of Cleaner Production, Vol. 112, pp. 2744-2755, http://doi.org/10.1016/j.jclepro.2015.10.023.

Kafel, P., Casadesus, M. (2016) "The order and level of management standards implementation: Changes during the time", TQM Journal, Vol. 28, No. 4, pp. 636-647, http://doi.org/10.1108/TQM-02-2015-0027.

Karcher, P., Jochem, R. (2015) "Success factors and organizational approaches for the implementation of energy management systems according to ISO 50001", The TQM journal, Vol. 27, No. 4, pp. 361-381, http://doi.org/10.1108/tqm-01-2015-0016.

Khatoun, R., Zeadally, S. (2016) "Smart cities: concepts, architectures, research opportunities", Communications of the ACM, Vol. 59, No. 8, pp. 46-57, http:// doi.org/10.1145/2858789.

Kim, K., Jung, J. K., Choi, J. (2016) "Impact of the smart city industry on the Korean national economy: Input-output analysis", Sustainability, Vol. 8, No. 7, p. 649 , http://doi.org/10.3390/su8070649.

Kitchin, R. (2014) "Making sense of smart cities: addressing present shortcomings", Cambridge Journal of Regions, Economy and Society, Vol. 8, No. 1, pp. 131136, http://doi.org/10.1093/cjres/rsu027.

Kitchin, R. (2016) "Getting smarter about smart cities: Improving data privacy and data security". Data Protection Unit, Department of the Taoiseach, Dublin, Ireland. Available at: <http://www.taoiseach.gov.ie/eng/ Publications/ Publications_2016/Smart_Cities_Report_January_2016.pdf> [Accessed: October 4, 2018]

Lee, J. H., Hancock, M. G., Hu, M. C. (2014) "Towards an effective framework for building smart cities: Lessons from Seoul and San Francisco", Technological Forecasting and Social Change, Vol. 89, pp. 80-99, http://doi.org/10.1016/j. techfore.2013.08.033.

Liebesman, S. (2008) "How to manage risk in a global economy", Quality Progress, Vol. 41, pp. 58-60. 
Loconto, A., Busch, L. (2010) "Standards, techno-economic networks, and playing fields: Performing the global market economy", Review of International Political Economy, Vol. 17, No. 3, pp. 507-536, http://doi.org/10.1080/09692290903319870.

McClellan, S., Jimenez, J. A., Koutitas, G. (2017) Smart cities: Applications, technologies, standards, and driving factors, Smart Cities: Applications, Technologies, Standards, and Driving Factors, http://doi.org/10.1007/978-3319-59381-4.

Mesquida, A. L., Mas, A. (2015) "Integrating IT service management requirements into the organizational management system", Computer standards \& interfaces, Vol. 37, pp. 80-91, http://doi.org/10.1016/j.csi.2014.06.005.

Mijatovic, I., Horvat, A., Maricic, M. (2018) "Does National Participation in the International Standardization Influence the Level up to which Cities Act Sustainably?". In 23rd EURAS Annual Standardisation Conference. Dublin.

Mikulis, J., Ruževičius, J. (2009) "Management systems and competitiveness of a country-Lithuanian context", Current issues of Business and Law, Vol. 3, pp. $26-46$.

Nam, T., Pardo, T. A. (2011) "Smart city as urban innovation: Focusing on management, policy, and context". In Proceedings of the 5th international conference on theory and practice of electronic governance (pp. 185-194). ACM.

Nardo, M. et al. (2005) Handbook on constructing composite indicators, OECD Statistics Working Papers. http://doi.org/10.1787/533411815016.

Neirotti, P. et al. (2014) "Current trends in Smart City initiatives: Some stylised facts”, Cities, Vol. 38, pp. 25-36, http://doi.org/10.1016/j.cities.2013.12.010.

Neumayer, E., Perkins, R. (2004) "What explains the uneven take-up of ISO 14001 at the global level?-A Panel-Data Analysis", Environment and Planning A, Vol. 36, No. 5, pp. 823-839, http://doi.org/10.1068/a36144.

Picatoste, J. et al. (2018) "Smart cities for wellbeing: youth employment and their skills on computers", Journal of Science and Technology Policy Management, Vol. 9, No. 2, pp. 227-241, http://doi.org/10.1108/JSTPM-04-2017-0014.

Prange-Gstöhl, H. (2009) "Enlarging the EU's internal energy market: Why would third countries accept EU rule export?", Energy Policy, Vol. 37, No. 12, pp. 5296-5303, http://doi.org/10.1016/j.enpol.2009.07.070.

Raweni, A. M., Majstorović, V. D. (2016) "ISO certifications diffusion in European countries 2007-2014 and forecasting for 2022-stare of the art", International Journal “Advanced Quality”, Vol. 44, No. 1, pp. 53-58, http://doi.org/10.25137/ IJAQ.n1.v44.y2016.p53-58.

Reinartz, W., Haenlein, M., Henseler, J. (2009) "An empirical comparison of the efficacy of covariance-based and variance-based SEM", International Journal of Research in Marketing, Vol. 26, No. 4, pp. 332-344, http://doi.org/10.1016/j. ijresmar.2009.08.001. 
Ringle, C. M., Schlittgen, R. (2007) "A genetic algorithm segmentation approach for uncovering and separating groups of data in PLS path modeling". In PLS'07: 5th International Symposium on PLS and Related Methods, pp. 75-78.

Romão, J. et al. (2018) "The smart city as a common place for tourists and residents: A structural analysis of the determinants of urban attractiveness", Cities, Vol. 78, pp. 67-75, http://doi.org/10.1016/j.cities.2017.11.007.

Ruso, J., Filipović, J. (2018) "How do international standards support the development of sustainable and smart cities?". In 1st International Conference on Production in Urban Environments, 17-19 October, Belgrade, Serbia, Faculty of Civil Engineering.

Safaee Pour, (2017) "Evaluation of City Prosperity Index in Iranian-Islamic Cities: A Case Study of Ahvaz Metropolis", Chinese Journal of Urban and Environmental Studies, Vol. 5, No. 4, p. 1750025, http://doi.org/10.1142/s2345748117500257.

Samarakoon, S. B. R. G. K., Rajini, P. (2013) "Enablers and barriers of implementing ISO 50001-energy management systems (EnMS) in Sri Lankan context". In The second World Construction Symposium 2013: Socio-Economic Sustainability in Construction. Colombo, Sri Lanka: CIB-SB13, Vol. 2, pp. 208-217.

Sampaio, P., Saraiva, P., Guimarães Rodrigues, A. (2009) "ISO 9001 certification research: questions, answers and approaches", International Journal of Quality \& Reliability Management, Vol. 26, No. 1, pp. 38-58, http://doi.org/10.1108/ 02656710910924161.

Saraiva, P. M., Duarte, B. (2003) "ISO 9000: some statistical results for a worldwide phenomenon", Total Quality Management \& Business Excellence, Vol. 14, No. 10, pp. 1169-1178, http://doi.org/10.1080/1478336032000107726.

Science for Environment Policy (2018) "Indicators for sustainable cities", In-depth Report 12. Produced for the European Commission DG Environment by the Science Communication Unit, Bristol: UWE. Available at: <http://ec.europa.eu/ science-environment-policy> [Accessed: May 30, 2019]

Sepasgozar, S. M. E. et al. (2019) "Implementing citizen centric technology in developing smart cities: A model for predicting the acceptance of urban technologies", Technological Forecasting and Social Change, Vol. 142, pp. 105-116, http://doi.org/10.1016/j.techfore.2018.09.012.

Steele, R. (2013) "Simpler, faster, better and smarter ISO's challenge", ISO Focus +, Vol. 4, No. 1, pp. 1.

Stein, C. M., Morris, N. J., Nock, N. L. (2012) "Structural Equation Modeling”. In Elston, R., Satagopan, J., and Shuying, S. (eds) Statistical Human Genetics, pp. 495-512, http://doi.org/10.1007/978-1-61779-555-8_27.

Swinnen, J. et al. (2015) Quality standards, value chains, and international development: Economic and political theory, Quality Standards, Value Chains, and International Development: Economic and Political Theory. http://doi. org/10.1017/CBO9781139198912. 
To, W.-M., Lee, P. K. C., Lam, K.-H. (2018) "Building professionals' intention to use smart and sustainable building technologies - An empirical study", PLOS ONE, Edited by M. A. Berawi, Vol. 13, No. 8, pp. 1-17, http://doi.org/10.1371/ journal.pone.0201625.

To, W. M., Lee, P. K. C. (2014) "Diffusion of ISO 14001 environmental management system: global, regional and country-level analyses", Journal of Cleaner Production, Vol. 66, pp. 489-498, http://doi.org/10.1016/j.jclepro. 2013.11.076.

Trajković, A., Milošević, I. (2016) "Model to determine the economic and other effects of standardisation-a case study in Serbia", Total Quality Management \& Business Excellence, Vol. 29, No. 5-6, pp. 673-685, http://doi.org/10.1080/1478 3363.2016.1225496.

Tranchard, S. (2013) "Building smart cities. How ISO standards contribute", ISO Focus + , Vol.4, No. 1, pp. 9.

Tunçalp, D. (2014) "Diffusion and adoption of information security management standards across countries and industries", Journal of Global Information Technology Management, Vol. 17, No. 4, pp. 221-227, http://doi.org/10.1080/1 097198x.2014.982454.

Viengkham, M. (2017) "The system complexities of smart cities and the systems approach for standardization". In Smart Cities: Applications, Technologies, Standards, and Driving Factors. http://doi.org/10.1007/978-3-319-59381-4-3.

Vodă, A. I., Radu, L. D. (2018) "Investigating Economic Factors of Sustainability in European Smart Cities", European Journal of Sustainable Development, Vol. 7, No. 1, pp. 107-120, http://doi.org/10.14207/ejsd.2018.v7n1p107.

Watson, I., Krislov, S. (2006) "How Nations Choose Product Standards and Standards Change Nations", Contemporary Sociology, Vol. 27, No. 2, pp. 169, http://doi.org/10.2307/2654795.

Westlund, Anders H., Mari Källström, and Johan Parmler. "SEM-based customer satisfaction measurement: On multicollinearity and robust PLS estimation." Total Quality Management,Vol. 19, No. 7-8, pp. 855-869, http://doi. org/10.1080/14783360802159527.

Williams, J. A. (2004) "The impact of motivating factors on implementation of ISO 9001:2000 registration process", Management Research News, Vol. 27, No. 1/2, pp. 74-84, http://doi.org/10.1108/01409170410784365.

Yuriev, A., Boiral, O. (2018) "Implementing the ISO 50001 System: A Critical Review". In ISO 9001, ISO 14001, and New Management Standards (pp. 145175). Springer, Cham.

Zahra, S. A., George, G. (2002) "Absorptive capacity: A review, reconceptualization, and extension", Academy of Management Review, Vol. 27, No. 2, pp. 182-203, http://doi.org/10.5465/AMR.2002.6587995. 
Zgodavova, K., Bober, P. (2012) "An innovative approach to the integrated management system development: SIMPRO-IMS web based environment", Quality Innovation Prosperity, Vol. 16, No. 2, pp. 59-70.

\title{
Utječu li međunarodni standardi na razvoj pametnih regija i gradova?
}

\author{
Jelena Ruso ${ }^{1}$, Ana Horvat ${ }^{2}$, Milica Maričic ${ }^{3}$
}

\begin{abstract}
Sažetak
Rast gradskog stanovništva utječe na održivost $i$ razvoj pametnih regija. Međunarodni standardi mogu pružiti dobre prakse u širokim područjima koja se odnose na ekološke, sigurnosne $i$ društvene aspekte koji doprinose postizanju gospodarskog i održivog rasta, dobrobiti i sigurnosti okoliša. Cilj ove studije je istražiti postoji li povezanost između razine pametnih gradova u različitim regijama $i$ broja certifikata koji bi mogli pokrenuti daljnji razvoj pametnih $i$ održivih gradova. Analizirali smo standarde koji podržavaju razvoj održivih $i$ pametnih gradova iz različitih zemalja i istražili njihov utjecaj na razinu pametnih $i$ održivih gradova. Za mjerenje uspješnosti gradova koristili smo UN-ovu inicijativu za prosperitet grada (CPI) i njezinih šest dimenzija: produktivnost, razvoj infrastrukture, kvalitetu života, jednakost i društvenu uključenost, održivost okoliša $i$ urbano upravljanje $i$ zakonodavstvo. Za analiziranje utjecaja međunarodnih standarda na inicijativu pametnih regija $i$ gradova proveli smo SEM analizu. Rezultati istraživanja potvrđuju da postoji značajna razlika između razine pametnih gradova u različitim regijama i broja certifikata koji bi mogli pokrenuti daljnji razvoj pametnih $i$ održivih gradova. Nadalje, potvrđen je pozitivan utjecaj međunarodnih standarda na razvoj pametnih regija i gradova. Vjerujemo da predstavljeni pristup može pružiti dodatni uvid u čimbenike koji utječu na razvoj pametnih regija i gradova i pokrenuti daljnja istraživanja o toj temi.
\end{abstract}

Ključne riječi: međunarodni standardi, pametni gradovi, Gradska inicijativa za prosperitet (CPI), SEM analiza

JEL klasifikacija: R11, O44, L15, C30

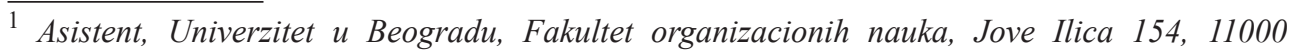
Beograd, Srbija. Znanstveni interes: upravljanje kvalitetom, standardizacija, javna uprava. Tel.: +3813950936.E-mail: jelena.ruso@fon.bg.ac.rs (osoba za kontakt).

2 Docent, Univerzitet u Beogradu, Fakultet organizacionih nauka, Jove Ilica 154, 11000 Beograd, Srbija. Znanstveni interes: standardizacija, upravljanje kvalitetom, liderstvo. Tel.: +381113950936.E-mail: horvat.ana@fon.bg.ac.rs.

3 Asistent, Univerzitet u Beogradu, Fakultet organizacionih nauka, Jove Ilica 154, 11000 Beograd, Srbija. Znanstveni interes: računalna statistika, multivarijantna analiza, znanost o podacima.Tel.: +381113950822.E-mail: milica.maricic@fon.bg.ac.rs. 